\title{
Pectinase production by Aspergillus niger using wastewater in solid state fermentation for eliciting plant disease resistance
}

\author{
Z.H. Bai ${ }^{\text {a }}$, H.X. Zhang ${ }^{\text {a,* }}$, H.Y. Qi ${ }^{\text {a }}$, X.W. Peng ${ }^{\text {a }}$, B.J. Li ${ }^{b}$ \\ a Department of Environmental Bio-Technology, The Research Center for Eco-Environmental Sciences, Chinese Academy of Sciences, \\ P.O. Box 2871, Beijing 100085, China \\ ${ }^{\mathrm{b}}$ The Institute of Vegetables and Flowers, Chinese Academy of Agricultural Sciences, Beijing 100081, China
}

Received 2 February 2003; received in revised form 16 May 2003; accepted 15 June 2003

Available online 27 March 2004

\begin{abstract}
An elicitor of plant disease resistance, pectinase, was produced by solid state fermentation with Aspergillus niger. Sugar beet pulp was used as carbon source and the wastewater from monosodium glutamate production was used as nitrogen and water source. The composition of the fermentation medium was: $11 \mathrm{ml}$ concentrated wastewater (containing $\mathrm{NH}_{3}-\mathrm{N} 38.2 \mathrm{mg} / \mathrm{ml}$ ), sugar beet pulp $10 \mathrm{~g}$, $\mathrm{Na}_{2} \mathrm{HPO}_{4} \cdot 12 \mathrm{H}_{2} \mathrm{O} 0.2 \mathrm{~g}, \mathrm{KH}_{2} \mathrm{PO}_{4} 0.04 \mathrm{~g}$ in a $500 \mathrm{ml}$ Erlenmeyer flask. The fermentation temperature was $30{ }^{\circ} \mathrm{C}$ and the relative humidity of the air was $75-90 \%$. The maximum production of pectinase was reached after $96 \mathrm{~h}$ cultivation. The crude pectinase extracted from the fermented materials could elicit disease resistance in cucumber and tomato seedlings.
\end{abstract}

(C) 2004 Elsevier Ltd. All rights reserved.

Keywords: Aspergillus niger; Pectinase; Wastewater; Elicitor; Plant disease resistance

\section{Introduction}

Pectinase comprises a heterogeneous group of enzymes that catalyze the breakdown of pectin-containing substrates. They are widely used in the food industry to improve the cloud stability of fruit and vegetable nectars, for production and clarification of fruit juices, and for haze removal from wines (Cavalitto et al., 1996). Furthermore, phytopathologic studies have reported that fungal endo-polygalacturonase (endoPGase) which is a major kind of pectinase has been shown to activate plant defense responses, including phytoalexin accumulation, lignification, synthesis of proteinase inhibitors, and necrosis (Cervone et al., 1989). Further research has confirmed that the mechanism is that the endoPGase can degrade the plant cell wall releasing pectic oligomers which can stimulate a wide array of plant defence responses (Côté and Hahn, 1994; Boudart et al., 1998).

With the increasing application of pectinase, decreasing its production cost has become one of the

\footnotetext{
${ }^{*}$ Corresponding author. Tel.: +86-10-6284-9155; fax: +86-10-62923563.

E-mail address: hxzhang@mail.rcees.ac.cn (H.X. Zhang).
}

most important targets. For this purpose, the selection of carbon source and nitrogen source with low value is a practical consideration. Previous research has reported that many waste products from the agricultural industry containing pectin, such as sugar beet pulp (SBP), citrus pulp pellets, apple pomace, henequen pulp, lemon pulp and other related materials have been used as carbon source for induction of pectinase by many microorganisms (Said et al., 1991). But the alternative nitrogen source with low value or from waste has not been noted so far. Considering the possibility of using a wastewater containing a high concentration of $\mathrm{NH}_{3}-\mathrm{N}$ for supplying microorganisms with a nitrogen source, we decided to study its utilization for production of pectinase. As far as the authors are aware, no papers have been published on this subject.

Monosodium glutamate wastewater (MGW), which is generated from monosodium glutamate production, has high levels of $\mathrm{COD}$, sulfate and $\mathrm{NH}_{3}-\mathrm{N}$ with low $\mathrm{pH}$ value. It is very costly to treat the MGW for discharging at the national standard. In this paper, the one of MGW and the SBP for pectinase production by $A$. niger was investigated.

In addition, reports on eliciting plant resistant disease using pectinase were still limited and not specific. In this 
paper, the elicitation of plant disease resistance by the pectinase was also investigated.

\section{Methods}

\subsection{Fermentation substrates}

The sugar beet pulp (SBP) employed was obtained from a sugar plant located in the Northeast area of China. It was used as the carbon source and was of the following composition ( $\%$ on dry basis): pectin, 28.7; cellulose, 20.0; hemicellulose, 17.5; protein, 9.0; lignin, 4.4; fat, 1.2; ash, 5.1 (Xue et al., 1992). The high pectin content could be very helpful for pectinase production.

The MGW was obtained from a monosodium glutamate plant located in Shandong Province, China. In the wastewater, the elements were analyzed by inductively coupled plasma-atomic emission spectrometry (ICP-AES); the total nitrogen was determined by a Kjeldahl method; the $\mathrm{NH}_{4}^{+}$was determined by the Formaldehyde method; the $\mathrm{SO}_{4}^{2-}$ was determined by an EDTA titration method; the reducing sugar (mainly the residual glucose in monosodium glutamate fermentation) was determined by the 3,5-dinitrosalicylic acid (DNS) method; and the $\mathrm{pH}$ was determined by $\mathrm{pH}$ meter. The MGW was concentrated by a rotary evaporator with reducing pressure to $\mathrm{NH}_{3}-\mathrm{N} 38.2 \mathrm{mg} / \mathrm{ml}$, and $\mathrm{pH}$ was adjusted to 7.0 by $\mathrm{NaOH}$, then used for the culture medium.

\subsection{Microorganism and culture conditions}

A. niger CGMCC0455 was isolated by our laboratory for pectinase production (Zhang and Qi, 2000). The strain was maintained on potato glucose agar slants in a refrigerator, and subcultured every six months. The fermentation medium in a $500 \mathrm{ml}$ Erlenmeyer flask contained: dry sugar beet pulp $10 \mathrm{~g}, \mathrm{Na}_{2} \mathrm{HPO}_{4} \cdot 12 \mathrm{H}_{2} \mathrm{O}$ $0.2 \mathrm{~g}, \mathrm{KH}_{2} \mathrm{PO}_{4} 0.04 \mathrm{~g}$, water $11 \mathrm{ml}$, and the appropriate nitrogen source. The medium was mixed and inoculated with $2 \times 10^{6}$ spores per gram of wet substrate. The flasks were placed in a humid cultivation chamber with a gentle circulation of air at $30^{\circ} \mathrm{C}$, under static conditions for $96 \mathrm{~h}$.

\subsection{Enzyme assays}

After cultivation, the crude pectinase was extracted by mixing $20 \mathrm{~g}$ of fermented materials with $50 \mathrm{ml}$ of distilled water, squeezing at $60 \mathrm{~kg} / \mathrm{cm}^{2}$ in a hydraulic press and then filtering through a $0.45 \mu \mathrm{m}$ membrane filter (Whatman). It was stored at $4{ }^{\circ} \mathrm{C}$ for enzymatic measurements.

The activity of the endopectinase was measured by the AJDA method according to Friedrich et al. (1989).
One unit (AJDAu) of endopectinase activity was defined as that amount of enzyme which would degrade $1 \mathrm{mg}$ pectin (from citrus fruits, methoxy content $8 \%$, Sigma) at $\mathrm{pH} 4.2$ and $40^{\circ} \mathrm{C}$ in half an hour.

The activity of the polygalacturonase (PGase) was assayed by measuring the reducing groups released from polygalacturonic acid (from citrus fruits, Sigma) using the 3,5-dinitrosalicylic acid method with D-galacturonic acid monohydrate (Sigma) as the standard. One unit (RGu) of PGase activity was defined as that amount of enzyme which would yield $1 \mu \mathrm{mol}$ reducing ends per minute at $40{ }^{\circ} \mathrm{C}$ and $\mathrm{pH} 4.2$.

Pectin lyase activity was assayed by monitoring the increase in absorbance at $235 \mathrm{~nm}$, according to Jain et al. (1990). The reaction was carried out at $30^{\circ} \mathrm{C}$ in a total volume of $2.5 \mathrm{ml}$ containing $0.25 \%$ esterified pectin (degree of esterification 89\%, Sigma) and $0.05 \mathrm{M}$ sodium citrate buffer ( $\mathrm{pH}$ 6.2). One unit (UVu) of pectin lyase activity was defined as the activity that caused an increase in absorbance of 0.01 per min at $235 \mathrm{~nm}$ under these reaction conditions.

\subsection{Elicitor bioassay}

Cucumber and tomato seedlings were obtained from the Institute of Vegetables and Flowers, Chinese Academy of Agricultural Sciences. Thirty specimens, with no signs of necrosis or mechanical damage, were used for each assay. Experiments were run in triplicate and results given correspond to the average. According to preliminary tests, the samples to be assayed for elicitor activity were diluted with filter sterilized water (containing $0.02 \%$ Tween 20 ) to $30 \mathrm{AJDAu} / \mathrm{ml}$. The pectinase solution and the sterilized water (or boiled pectinase solution) as the control were separately sprayed on the plant seedlings once every two days. After treating three times, the spore solutions of several pathogens were separately sprayed on the plant seedlings both treated with the pectinase solution and the controls. When the diseases were obviously developed on the control cucumber seedlings, the infective index of each treatment seedlings was separately counted as described by the National Standard Methods of China (Wu et al., 2000).

\section{Results and discussion}

\subsection{Selection of the microorganism}

Commercial pectinase preparations are obtained mainly from Aspergillus and Penicillium (Said et al., 1991). A. niger is one of the most important microorganisms used in biotechnology. It has been in use already for many decades to produce extracellular (food) enzymes and citric acid. It is a safe production organism (Schuster et al., 2002). From several strains of $A$. niger, a 
strain A. niger CGMCC0455 having the highest level of pectinase production was selected for the present tests.

\subsection{Composition of the $M G W$}

The composition of the MGW is very complicated. The components determined were given as follows: Trace element (mg/l): Ba, 0.932; Ca, 389; Co, 0.0123; $\mathrm{Cu}, 0.605 ; \mathrm{K}, 259 ; \mathrm{Mg}, 79.0 ; \mathrm{Pb}, 0.588 ; \mathrm{Sr}, 0.869 ; \mathrm{Zn}$, 1.80; Mn, 2.66; Fe, 4.28; Na, 794; Cr, 0.862; P, 81.4; S, $15581 ; \mathrm{V}, 0.0082$. Compounds (\%): $\mathrm{SO}_{4}^{2-}, 4.06$; total nitrogen, 1.20; $\mathrm{NH}_{4}^{+}, 1.17$; reducing sugar, 0.275 . The $\mathrm{pH}$ was 1.5. This shows that the level of most components in the wastewater was much higher than the national standard level for discharge, so the treatment for discharging is very difficult and expensive. Since $\mathbf{N H}_{4}^{+}$is a good nitrogen source for many microorganisms, so the MGW could possibly provide a nitrogen source for $A$. niger.

\subsection{Fermentation process}

Studies on phytopathology showed that endoPGase and endopolygalacturonic acid lyase, both of which belong in 'endopectinase', are elicitors of plant disease resistance (Cervone et al., 1989; Davis et al., 1984). So the endopectinase activity is the main target for production. According to the single factor experiment by increasing every compound addition and changing every fermentation condition gradually, optimal fermentation conditions were determined as follows: The fermentation medium consisted of $10 \mathrm{~g}$ dry SBP, $\mathrm{Na}_{2} \mathrm{HPO}_{4}$. $12 \mathrm{H}_{2} \mathrm{O} 0.2 \mathrm{~g}, \mathrm{KH}_{2} \mathrm{PO}_{4} 0.04 \mathrm{~g}$ and $\left(\mathrm{NH}_{4}\right)_{2} \mathrm{SO}_{4} 2.0 \mathrm{~g}$ (containing N $0.42 \mathrm{~g}$ ), tap water $11 \mathrm{ml}$. The temperature for endopectinase production was $30{ }^{\circ} \mathrm{C}$ and the relative humidity of the air was $75-90 \%$. When the tap water and $\left(\mathrm{NH}_{4}\right)_{2} \mathrm{SO}_{4}$ were replaced by the MGW containing $\mathrm{NH}_{4}^{+}$, the production rate of endopectinase reached to nearly the same level. According to the time-course of pectinase production by $A$. niger under the above conditions, the maximum activities of endopectinase was obtained in $96 \mathrm{~h}$. Since pectinase from A. niger is a group of pectin-degrading enzymes, the activities of PGase and pectin lyase were also determined. The maximum PGase activity was obtained in $108 \mathrm{~h}$ and the maximum pectin lyase activity was obtained in $96 \mathrm{~h}$.

\subsection{Selection of the nitrogen source}

Of the various nitrogen compounds tested for pectinase production (Table 1), high pectinase activities were obtained with $\left(\mathrm{NH}_{4}\right)_{2} \mathrm{SO}_{4}$, yeast extract powder, soya peptone, soybean pulp powder and the MGW. It is obvious that using the MGW for pectinase production is the most favorable, because the very difficult and expensive treatment of the MGW for discharging can be avoided, and the clear water saved can be used for various purposes in the factory. In addition, the cost of the MGW treatment for discharging can compensate for a part of the cost of the pectinase production.

\subsection{Elicitation of plant disease resistance}

Elicitation of plant disease resistance was tested with several strains of pathogen. The cucumber and tomato seedlings were separately treated with the crude pectinase solution and the sterilized water (or boiled crude pectinase solution). The effects of disease resistance are shown in Table 2. The results indicated that all of the seedlings treated with the crude pectinase had obtained an extensive resistance against disease. In addition, the seedlings treated with the boiled crude pectinase solution showed approximately the same infective index as that treated with the sterilized water. This confirmed that pectinase, a heat-labile component, is really involved in eliciting of plant disease resistance.

Table 1

Effect of different nitrogen sources on pectinase production by A. niger

\begin{tabular}{lclc}
\hline $\begin{array}{l}\text { Nitrogen source } \\
(\mathrm{N} 0.04 \text { g/g dry SBP })\end{array}$ & $\begin{array}{c}\text { Endopectinase yield } \\
\left(\times 10^{3} \text { AJDAu/g dry SBP }\right)\end{array}$ & $\begin{array}{l}\text { PGase yield } \\
\left(\times 10^{3} \text { RGu/g dry SBP }\right)\end{array}$ & $\begin{array}{l}\text { Pectin lyase yield } \\
\left(\times 10^{2} \text { UVu/g dry SBP }\right)\end{array}$ \\
\hline $\begin{array}{l}\text { Monosodium glutamate } \\
\left(\mathrm{NH}_{4}\right)_{2} \mathrm{SO}_{4}\end{array}$ & 9.49 & 2.10 & 6.00 \\
$\mathrm{NH}_{4} \mathrm{Cl}$ & 15.0 & 4.39 & 16.8 \\
$\mathrm{NH}_{4} \mathrm{NO}_{3}$ & 5.98 & 0.41 & 5.95 \\
$\mathrm{NaNO}_{3}$ & 2.90 & 0.97 & 5.56 \\
Tri-ammonium citrate & 3.41 & 1.28 & 0.99 \\
Urea & 8.42 & 1.37 & 6.00 \\
Soya peptone & 9.46 & 1.17 & 3.23 \\
Yeast extract powder & 14.6 & 3.21 & 11.5 \\
Wheat bran & 13.9 & 3.99 & 6.44 \\
Soybean pulp powder & 5.45 & 1.28 & 9.50 \\
MGW & 15.0 & 5.25 & 6.67 \\
No addition & 15.6 & 3.60 & 16.2 \\
\hline
\end{tabular}

The organism was grown for $96 \mathrm{~h}$ at $30{ }^{\circ} \mathrm{C}$. The experiments were run in triplicate and the relative deviation was less than $5 \%$. 
Table 2

Disease decrease of plant seedlings treated with the crude pectinase

\begin{tabular}{lll}
\hline Disease & Pathogen & Disease decrease $(\%)^{\mathrm{a}}$ \\
\hline Cucumber scab & Cladosporium cucumerinum & 44.5 \\
Cucumber downy mildew & Pseudoperonospora cubensis & 71.2 \\
Cucumber powdery mildew & Sphaerotheca fuliginea & 76.3 \\
Cucumber anthracnose & Colletotrichum orbiculare & 69.7 \\
Cucumber angular leaf spot & Pseudomonas syringae & 66.8 \\
Tomato leaf mold & Fulvia fulva & 20.7 \\
Tomato bacterial scab & Xanthomonas campestris & 70.9 \\
\hline
\end{tabular}

The experiments were run in triplicate and the relative deviation was less than $10 \%$.

${ }^{\mathrm{a}}$ Disease decrease $(\%)=\left(\mathrm{ID}_{\text {control }}-\mathrm{ID}_{\text {treatment }}\right) / \mathrm{ID}_{\text {control }} \times 100 \%$. $\mathrm{ID}_{\text {control }}$ means the infective index of the plant seedlings treated with sterilized water or boiled pectinase solution. $\mathrm{ID}_{\text {treatment }}$ means the infective index of the plant seedlings treated with crude pectinase solution.

In conclusion, it is feasible to use wastewater and agricultural byproducts for pectinase production. Not only would a valuable resource be saved, but also the pollution source would be decreased. It is well known that excessively using chemical germicide to protect plants from diseases could pollute the food and environment. Whereas, using the crude pectinase to protect plants from diseases could decrease the chemical germicide consumption.

\section{Acknowledgements}

This work was supported by " 863 " research project of China (2001 AA 246014). We acknowledge Aimei Zhao and Haiyan Fan for the assistance with partly bioassay of this work.

\section{References}

Boudart, G., Lafitte, C., Barthe, J.P., Frasez, D., Esquerré-Tugayé, M.-T., 1998. Differential elicitation of defense responses by pectic fragments in bean seedlings. Planta 206, 86-94.

Cavalitto, S.F., Arcas, J.A., Hours, R.A., 1996. Pectinase production profile of Aspergillus foetidus in solid state cultures at different acidities. Biotechnol. Lett. 18, 251-256.
Cervone, F., Hahn, M.G., Lorenzo, G.D., Darvill, A., Albersheim, P., 1989. Host-pathogen interactions XXXIII. A plant protein converts a fungal pathogenesis factor into an elicitor of plant defense responses. Plant Physiol. 90, 542-548.

Côté, F., Hahn, M.G., 1994. Oligosaccharins: Structure and signal transduction. Plant Mol. Biol. 26, 1379-1412.

Davis, K.R., Lyon, G.D., Karvill, A.G., Albershem, P., 1984. Hostpathogen interactions XXV. Endopolygalacturonic acid lyase from Erwinia Carotovora elicits phytoalexin accumulation by releasing plant cell wall fragments. Plant Physiol. 74, 52-60.

Friedrich, J., Cimerman, A., Steiner, W., 1989. Submerged production of pectolytic enzymes by Aspergillus niger: Effect of different aeration/agitation regimes. Appl. Microbiol. Biotechnol. 31, 490 494.

Jain, S., Durand, H., Tiraby, G., 1990. Production of extacellular pectinase enzymes by a mutant (Pol6) of Penicillium occitanis. Appl. Microbiol. Biotechnol. 34, 308-312.

Said, S., Fonseca, M.J.V., Siéssere, V., 1991. Pectinase production by Penicillium frequentans. World J. Microbiol. Biotechnol. 7, 607608.

Schuster, E., Dunn-Coleman, N., Frisvad, J.C., Dijck, P.W.M., 2002. On the safety of Aspergillus niger-a review. Appl. Microbiol. Biotechnol. 59, 426-435.

Wu, X.P., Gu, B.G., Liu, N.Z., Zhu, Q.H., 2000. Pesticide-Guidelines for the Field Efficacy Trials. Standards Press of China, Beijing.

Xue, M., Liu, D., Zhang, H., Qi, H., Lei, Z., 1992. A pilot process of solid state fermentation from sugar beet pulp for the production of microbial protein. J. Ferment. Bioeng. 73, 203-205.

Zhang, H.X., Qi, H.Y., 2000. Pectinase production by Aspergillus niger using biomass waste in solid state fermentation. CN Patent 1271774A. 